\title{
A Rating System for Sustainability of Industrial Projects with Application in Oil Sands and Heavy Oil Projects: Origins and Fundamentals
}

\author{
Cesar A. Poveda \\ Department of Mechanical Engineering, University of Alberta \\ 4 - 9 Mechanical Engineering Building, University of Alberta, Edmonton, Alberta T6G 2G8, Canada
}

Tel: 1-780-619-1872Ｅ-mail: poveda@ualberta.ca

Michael G. Lipsett (Corresponding Author)

Department of Mechanical Engineering, University of Alberta

5 - 8J Mechanical Engineering Building, University of Alberta, Edmonton, Alberta T6G 2G8, Canada

Tel: 1-780-492-9494 E-mail: mlipsett@ualberta.ca

Received: February 7, 2011

Accepted: February 27, 2011

doi:10.5539/jsd.v4n3p59

\begin{abstract}
Measures for assessing the environmental impact and long-term sustainability will become an increasingly important requirement in industrial project management. The concept of sustainability influences all aspects of a project, from its earliest phases: development procedures, design of facilities and infrastructure, operation of the industrial facility, and economics. Project management researchers and practitioners are working together to find effective and efficient methods and techniques to minimize the environmental impact that projects carry. Sustainable rating systems are structured decision-making tools in support of measuring environmental performance throughout the project life cycle, not only complying with government \& non-government regulations, but also meeting internal and external standards, procedures, processes, and requirements. The majority, if not all, rating systems created to date focus on buildings and residential housing construction. This paper introduces the development of a rating system to measure the environmental performance of oil sands and heavy oil projects, called the WA-PA-SU project sustainability rating system. A brief history of the concept of sustainability is discussed, and correlated with the three integrated areas related to the development of a sustainable rating system for this industrial sector: oil sands and heavy oil projects, regulations, and rating systems. The paper also discusses the tools and techniques applied in the development methodology of a sustainable rating system, lists some of the expected benefits based on previous use of others ratings systems around the world, and finally concludes with an outline of future research.
\end{abstract}

Keywords: Sustainable development, Environmental issues, Ratings, Energy efficiency, Energy consumption

\section{Introduction}

There are many definitions of sustainability. In 1987, the World Commission and Environmental Development defined sustainability as: "Development that meets the needs of the present without compromising the ability of future generations to meet their own needs" (United Nations, 1987). Based on this definition of sustainability, any project that carries a level of environmental impact requires mitigation activities to meet sustainability goals. Alternatively, the project must define the nature and extent of impacts so that other projects may be developed to offset these impacts to meet sustainability goals. The main challenge for practitioners and researchers is to develop an appropriate tool to measure not only the environmental impact of a project during development and construction, but also to estimate how sustainable a project will be in the long term.

Environmental impact plays a key role in the development of most projects. Project considerations throughout the life cycle of a project include: the project size, kind of industry, surroundings, codes, standards, regulations, and stakeholder requirements. A tool used in the construction industry to support these objectives is the sustainable rating system. This rating system is a third-party verification that measures the environmental performance of a project (U.S. Green Building Council, 2011). 
While sustainable rating systems are tools commonly used in the construction industry, they have been developed focusing on the assessment of the environmental high-performance of buildings. This approach can be readily adapted to other industries.

Production of unconventional fossil fuel from heavy oil reservoirs and extra heavy (bitumen) from oil sands deposits is one of the biggest sectors of the Canadian economy, and an increasingly important strategic source of global hydrocarbon supply. Given the energy required to produce transportation fuels from heavy and extra-heavy sources, land disturbance \& water use, and greenhouse gas generation associated with extraction, conversion, and transportation, there are obvious negative environmental impacts. Oil sands and heavy oil projects have not yet been part of the green rating systems movement, although there are some metrics for assessing the environmental impact of these projects established by legal requirements (regulations) (Alberta Energy, 2011a).

Sustainable rating systems can provide benefits to society by allowing industrial projects to be assessed using agreed upon metrics for economic performance, effects on worker health, non-economic social benefits to a region, and environment impacts. Projects that have used any kind of green rating system perform environmentally more efficiently when compared to those conventionally built to construction codes. The range of benefits of green practices have been documented (Yudelson, 2008) and measured from the cost and financial-benefit point-of-view (Issa, 2009). While some advocates claim safety benefits and better living environments in certified projects (that is, projects that make use of a rating system), others have not found compelling evidence of such benefits (Rajendran et al., 2009). This may be because the rating system does not track safety or quality of the built environment. The green and sustainability movement has made a compelling argument for project practitioners to develop methods to track environmental performance of projects.

\section{Areas of Integration}

To develop a project sustainability rating system, the general scope of an industrial project needs to be defined; the inputs, processes, and outputs need to be identified; and the requirements to be met must be set, with methods for making measurements. In the case of oil sands and heavy oil projects, the WA-PA-SU ${ }^{1}$ project sustainability rating system is being developed to include the technology base of the project, its associated infrastructure, relevant regulations, standards, procedures, and non-regulatory requirements.

It is necessary to analyze and document best practices in each of these three major areas, in order to create an effective and efficient tool to measure environmental performance. Figure 1 shows the relationship between areas of integration and the parties involved in each area of integration. A dotted line represents a link that may be missing between the areas of integration, which is the main objective in the development of the sustainable rating system for oil and heavy oil projects.

\subsection{Key Application Sector: Oil Sands and Heavy Oil Projects}

Oil sand is a source of unconventional, extra-heavy fossil fuel. Oil sand comprises bitumen in an unconsolidated matrix of sand, clays, and water. The largest proven reserves of oil sands and heavy oil deposits are located in Canada, with about $80 \%$ of the world's currently recoverable bitumen, and Venezuela, with proven reserves of extra-heavy crude oil representing about $75 \%$ of current heavy oil supply. Other deposits occur in United States, Russia, Colombia, Brazil, some countries in the Middle East, and others (Kelly, 2009).

Unconventional fossil fuels are not considered to be part of global proven reserves until technology is demonstrated to extract the oil efficiently and reasonably cost effectively. Declining reserves of conventional petroleum, the increasing price of oil, and the development of new technology options for oil extraction have improved reliability and cost-effectiveness of oil sands and heavy oil exploitation to the point that oil sands are now considered to be part of the world's proven oil reserves (Alberta Energy, 2009). Some studies indicate that in 2009, Albert's total proven oil reserves were 171.3 billion barrels counting for $13 \%$ of total global oil reserves; by 2019 the crude bitumen production from the Alberta's oil sands projects is expected to more than double to 3.2 million barrels per day (Alberta Energy, 2011b)

Global demand for energy is increasing and will grow by approximately 50\% by 2030 (International Energy Agency, 2010). Heavy hydrocarbon will have a significant impact on future petroleum extraction and its associated environmental effects. Oil sands and heavy oil projects are driven primarily by geotechnical, economic, and geopolitical considerations (Herbst, 2004; Watkins, 2007). The pace of development for such projects is expected to increase, with governments and oil companies interested in the potential of heavy and extra-heavy oil (Nikiforuk, 1997; Kelly, 2009; Moritis, 2007). Although companies are facing not only financial but also environmental challenges in their efforts to keep up with global oil consumption (Cetron and Davies, 
2010; U.S. Government Accountability Office, 2007) there is not a consistent method for assessing how technologies and practices can address these challenges.

Kelly (2009) explains the most common bitumen extraction methods, categorizing them in two basic processes:

1) mining the sands for bitumen separation in mineral processing plants, and

2) recovering the oil in-situ (that is, extracting oil without processing the oil sand itself).

Surface mining is appropriate for orebodies that are close to the surface and which are fairly contiguous. Bitumen recovery from a surface mineable oil sands deposit is on the order of $90 \%$. After overburden removal, the current mining method consists of a five-stage process: (1) the ore is removed from the mine face and moved to a crusher, (2) a crusher reduces lumps of ore to smaller size, (3) the crushed oil sand is mixed with warm water to form a slurry, (4) pipelines move the oil sands slurry from the mine to an extraction plant in a process called hydrotransport, which conditions the slurry to prepare the bitumen for separation from the sand and clay, and (5) a separation circuit separates a bitumen-laden froth for further processing, and directs the nonproduct materials (sand, water, and fine solids) to tailings impoundments (Kelly, 2009).

The depth of oilsand deposits varies. Athabasca oil sands deposits in Northern Alberta may be within $75 \mathrm{~m}$ of the surface; $500 \mathrm{~km}^{2}$ are under surface mining exploitation of a total of 140,000 km (Alberta Energy, 2009). Surface-based operations use large-capacity excavating shovels to load off-road haul trucks that carry up to 400 tons of ore. Surface mining produces a barrel of crude oil using approximately 2.5 to 4 barrels of water (Canada Association of Petroleum Producers, 2010) and two tons of oil sand (Alberta Energy, 2009).

The non-product outputs of the mining and extraction process include sediments, water, and small portion of residual oil (approximately 3\% carries over), which is placed in settling basins (Kelly, 2009). These large areas, also known as tailing ponds, allow coarse sand to settle, trapping fine solids and water. Process-affected water id decanted from the basin and recycled. Presently, tailing ponds approximately cover $170 \mathrm{~km}^{2}$ due to operations in Alberta. Given the long life cycle of an operating plant, settling basins and partially reclaimed land are part of the tailings management system for up to 30 - 40 years (Canada Association of Petroleum Producers, 2010).

About $80 \%$ of the oil sands in Alberta are buried too deep to be recovered using surface mining (Energy Albert, 2009). A variety of in-situ processes have been developed, all based on reducing the viscosity of the bitumen in place so that the hydrocarbon will flow into a production well due to a pressure gradient in porous soil. In-situ processes rely primarily on adding thermal energy in the form of steam.

In-situ processes require water resources nearby and sophisticated drilling methods, resulting in the need for efficient recovery factors and water use (Oil Sands Discovery Center, 2010). In-situ processes in the oil sands projects in Alberta use about 17 million $\mathrm{m}^{3}$ per year, increasingly using saline groundwater instead of fresh water as producers are moving away from using fresh water for steam production to brackish water (Canadian Association of Petroleum Producers, 2009). Surface and in-situ projects can have water recycle rates as high as 90\% (Alberta Energy, 2011b).

Steam injection methods attempt to achieve low steam-to-oil ratios so that there is a low amount of thermal energy input for the hydrocarbon energy output. These methods are sometimes augmented with solvents or reagents to promote good recovery without fast loss of porosity in the formation (Galvao et al., 2009). The two dominant methods are Cyclic Steam Stimulation and Steam Assisted Gravity Drainage.

In the Cyclic Steam Stimulation (CSS) method, a well is put through cycles of steam injection, soaking, and oil production. In the first step, the steam is injected into a well for a period of weeks to months; then, the well is allowed to sit for days to weeks to allow heat to soak into the formation. Later, the hot oil is pumped out of the well for a period of weeks or months. The advantage of this method is the recovery factor from deep deposits, which is around 20 to $25 \%$, and the disadvantage is the high cost to inject steam (Sunshine Oilsands Ltd., 2011).

Steam Assisted Gravity Drainage (SAGD) has a higher reliance on directional drilling. Well pairs are drilled - one close to the bottom of an oil sands deposit, and the other about 5 meters above the first well. Wells are drilled in groups off central pads, and can extend for kilometers in every direction. Steam is injected into the upper well, and the heat reduces the viscosity of the bitumen, which allows the bitumen to flow into the lower well, from which the hydrocarbon is then pumped to the surface. Depositional characteristics are important, especially an appropriate cap of rock to prevent depressurization, and staying away from water contact, which affects heating of the formation. "The choice between the CSS and SAGD processes in any in situ well is strictly determinate by the formation" (Kelly, 2009).

Another in-situ process similar to the SAGD method has been demonstrated: the Vapor Extraction Process (VAPEX), an extraction method that injects a light hydrocarbon solvent instead of steam. VAPEX is potentially 
more energy efficient than steam injection, and it has been demonstrated to do some partial upgrading of bitumen (breaking hydrocarbon chains) right in the formation. Potential disadvantages are solvent compression, solvent losses and potential sensitivity to reservoir heterogeneity (Luhning et al., 2003).

Finally, injecting air for a controlled combustion process burns a small fraction of the bitumen and generates high levels of heat to liquefy the bitumen. Toe-to-Heel-Air-Injection (THAI) uses this method by combining vertical air injection well with horizontal production well. The advantages of this method are that it requires less water, and has the potential to produces less greenhouse gases than standard steam injection methods, thereby presenting a smaller potential footprint than other production methods. Controllability issues include the maintenance of a stable flame front and preventing wormholing that disrupts the pressure gradient. These issues are the focus of demonstration prototyping using sensors downhole (Kelly, 2009).

The bitumen production methods described above produce a mixture of bitumen, solids, and connate water from the formation. Produced bitumen is ameliorated to remove excess water and solids before heavy oil upgrading into synthetic crude oil, which is in turn refined into transportation fuels. Solids and water are treated and disposed (Alberta Energy, 2009).

Oil sands and heavy oil projects are built on a large scale, not only by the value associated with their development, but also by their size and the number of people involved during the phases of planning, execution, operations, and related services. Although developing companies, regulatory agencies, and government monitor resources - such as air, water, and land - the environmental impacts have not been assessed in a consistent manner.

\subsection{Sustainable Rating Systems}

A new concept in the construction industry has become increasingly popular over the past twenty years to make projects more environmentally friendly. Green and sustainable construction focuses on increasing the efficiency of resource use - energy, water, and material — while reducing the construction impact on human health and the environment. This approach focuses on improved planning, design, construction, operation, maintenance, renovation and deconstruction compared to conventional remediation projects (U.S. Environmental Protection Agency, 2010).

Sustainable rating systems are assessment tools to measure environmental performance. Among other reasons, some of these sustainable rating systems have been updated from their original version to:

(1) satisfy the industry demand such as reducing buildings operating and maintenance cost and increasing building value among others benefits (Yudelson 2008);

(2) meet customer and stakeholder satisfaction by adopting efficient construction practices to minimize cost and deliver sustainable projects;

(3) decrease the environmental impact which can be accomplish, for example, by implementing improved technology, adopting improved processes and procedures, and minimizing energy consumption; and,

(4) comply with new and updated standards and regulations which are often included as criteria.

Sustainable rating systems are not only a decision making tool. They also can be used to measure environmental performance in a consistent manner for different technologies and practices. It may be difficult to determine which design variant has the best results for energy saving and $\mathrm{CO}_{2}$, because of a lack of calculation methods and techniques at the district level (Vreenegoor et al., 2008). Moreover, rating systems change with time and so they must be periodically reviewed and updated (Todd, 2009; Todd and Boecker, 2007).

Some of the most popular ratings systems are: ATHENA, BEAT 2002, BeCost (previously known as LCA-house), BEES 4.0, BREEAM, CASBEE, EcoEffect, EcoProfile, Eco-Quantum, Envest 2, Environmental Status Model (Miljostatus), EQUER, ESCALE, GB Tool, Green Globe, Green Start, LEED, LEGEP (previously know as Legoe), PAPOOSE, and TEAM. These and other currently used rating systems are listed in Table 1. Some of the building type assessed by these ratings system are: existing buildings, new buildings, refurbished buildings, building products/components, residential buildings (multi-unit), residential buildings (single family), and office buildings.

In the construction industry, these ratings are being used by architects, engineers, builders, producers of building products, investors and building owners, consultants, residents, facilities managers, researchers, regulatory authorities and government agencies, and - increasingly - users (Yudelson, 2008). Therefore, the ratings system can support a project throughout its life cycle, starting in the planning stage and finishing with disposal at the end of the project life cycle, as shown in Figure 2. Each rating system offers particular benefits depending upon 
the user, building type, and project life cycle phase, making comparison between different rating systems difficult (Haapio and Viitaniemi, 2008).

The most common and successful rating system, based on the number of projects certified and square per meter built, has been developed by the U.S. Green Building Council, is LEED, an acronym for Leadership in Energy and Environmental Design. The LEED green building program is a third-party certification that helps builders to adopt green and sustainable practices during the design, construction, and operation of high-performance buildings (U.S. Green Building Council, 2009a). LEED bases the environmental assessment on the "triple bottom line," a term coined by John Elkington in 1994 to denominate and coordinate three interests: "people, planet, and profit." LEED adopted this term and uses it as a foundation for its definition of sustainability, which is based in three similar aspects: social responsibility, environmental stewardship, and economic prosperity (U.S. Green Building Council, 2009a). (Post, 2007) states that the LEED system needs to be more focused on the performance of the building rather than implementation of new technology, because during the project operation phase a building may not meet the standards for a green and sustainable performance. Another claim made by experienced practitioners is based on the fact that the certification process is too complicated, and its criteria are not green and sustainable enough to meet the environmental challenges of high performance projects. As well, practitioners would like to see more credit points given for innovation and design (Post, 2007).

LEED rating systems address different types and scopes of projects: LEED for new construction and major renovations, LEED for core and shell, LEED for commercial interiors, LEED for schools, LEED for healthcare, LEED for retail, LEED for existing buildings (operations and maintenance), LEED for homes, and LEED for neighbourhood development. The strategy of the LEED rating system is to divide the project into six categories: sustainable sites, water efficiency, energy and atmosphere, material and resources, indoor environmental quality, and innovation in design. Each category comprises prerequisites and credits. Prerequisites are required elements and requirements that must be met to be eligible for any credit point; however, credit points are optional and meeting them adds points towards certification (U.S. Green Building Council, 2009b).

"While it is possible to build a LEED basic Certified and sometimes LEED Silver building at no additional cost, as buildings teams try to make a building truly sustainable, cost increments often accrue" (Yudelson, 2008). Using rating systems and applying green and sustainable technologies go hand-in-hand. The rating systems help to identify the areas where these technologies are needed to reduce environmental impact and meet regulations, standards, and requirements held by regulatory agencies, government, and/or stakeholders. Studies even suggest that the initial investment of $2 \%$ extra can even rise over ten times throughout the life cycle of the building (Kats et al., 2003); however, these costs can easily be mitigated due to the lower operational cost of environmentally high-performance buildings. The cost of design and construction added to green projects averages $1.84 \%$ including all certification levels, with a range between $0.66 \%$ (certified certification level) to $6.50 \%$ (platinum certification level). However, the return on investment is less than three years, with a large number of benefits facilitating the business case for green buildings: (1) economic (reduced operating costs, reduced maintenance costs, increased building value, tax benefits), (2) productivity, (3) risk management, (4) health, (5) public relations and marketing (stakeholder relations and occupant satisfaction, environmental stewardship, and a more competitive product in the market place), and (6) recruitment and retention (Yudelson, 2008).

Each sustainable rating system offers advantages and disadvantages, and practical comparisons among them have been extensively done (Haapio and Viitaniemi, 2008; Fenner and Ryce, 2007; Xiaoping et al., 2009). LEED has been compared to other rating systems such as Green Globe (Smith et al. 2004), which is another rating system that used in the U.S., but less popular than LEED. Although almost every developed country has a rating system in place, as Table 1 shows, other industries aside from the construction industry appear to have made less progress in the development of a rating system to rate their performance and compliance with environmental standards and regulations.

There are challenges that sustainable ratings systems face, for example, the implementation and integration of ratings within management processes and design. In general, the integration of sustainability and management can be done efficiently with great benefits for the construction industry. Eid (2004) integrated sustainable development into the project management processes using the Project Management Institute approach in project management. The challenges of integrating design and project delivery were laid out by Hellmund et al. (2008). $\mathrm{Wu}$ and Low (2010) studied some lessons for the ratings systems from the project management point of view, concluding that project management must be considered by practitioners, not only within the processes but also in practice when it comes to meeting the requirements of being green and sustainable. Integrated design can present great cost benefits playing a key role in a green project (Yudelson, 2008). Building information models have been used in the early stages to analyze consumption (Stumpf et al., 2009), and to evaluate sustainability of 
architectural design (Nguyen et al., 2010). Optimization models have helped in the selection of materials to meet a rating system requirement (Castro-Lacouture et al., 2009), among other benefits.

There is clear potential to apply an environmental monitoring framework to any construction and operation of a project that has ongoing environmental impact. The development of a sustainable rating system would contribute a potentially useful tool for assessing the impact of different technology options in oil sands and heavy oil projects.

\subsection{Regulations for Canadian Operations}

In Canada, oil sands and heavy oil projects are monitored closely for compliance with regulations and standards.

Regulatory agencies include both provincial and federal governments (depending on the jurisdiction). Even before a project is approved, an extensive scrutiny process takes place including the participation of ordinary citizens and other intervenors in a public hearing. At the provincial level, the main regulators in Alberta are: (1) Alberta Environment, (2) the Energy Resources Conservation Board (ERCB), and (3) Alberta Sustainable Resource Development. At the federal level, regulators include: (1) Environment Canada, (2) the Department of Oceans and Fisheries, and (3) Transport Canada (Oil sands developers group, 2009a). A licence to operate stipulates performance requirements above and beyond general regulations and standards. Even though Canadian oil sands and heavy oil projects operate within some of the most stringent and comprehensive environmental standards and regulations, they mainly focus on three resources: water, land, and air.

The Oil Sands Developers Group (2009b) describes the different regulators by resource: [1] The air resource is regulated by multiple authorities in the areas of air emissions and ambient air quality, and includes: Energy Resources Conservation Board (ERCB), Canadian Council of Ministers of the Environment (CCME), and Alberta Environment (AENV), among others. Emissions and air quality are also monitored by the Wood Buffalo Environmental Association (WBEA) [2]. The land resource presents challenges on its own: oil sands reclamation challenges are unique in the world (e.g., liquid tailing, pit lakes), and so the reclamation guidelines developed for the oil sands and heavy oil projects in Alberta are unique, and no exact equivalents can be found elsewhere in the world. Any regulatory approval requires participation in reclamation research through the Cumulative Environmental Management Association (CEMA) or the Canadian Oil Sands Network for Research and Development (CONRAD). The primary regulatory agencies are Environment Canada (AENV) and Alberta Resource Development (ASRD). [3] Water resources are monitored by the Regional Aquatics Monitoring Program (RAMP), and regulated by Alberta Environment (AENV) and the Department of Fisheries and Oceans (DFO), among others.

\section{Knowledge Gaps to Be Filled}

Having the means to assess the environmental impact of oil sands and heavy oil projects is crucial to support developers in finding more environmentally friendly processes, and to go beyond simply demonstrating their compliance to regulations. This is necessary when stakeholder expectations change, or when there is lack of agreement between developers and stakeholders. Some groups oppose any oil sands development, and there is no consensus on how oilsands development should be done. Reports in the media and from Environmental Non-Governmental Organizations (ENGOs) are at times highly critical of oil sands projects, not only on the grounds of the environmental performance but also perceptions of long-term negative impacts on the environment and on human health.

A communication problem does exist between the industry and the public in general: the industry is unable to effectively communicate to the community its efforts to minimize environmental impact and the results accomplished by investing in technology to make effective use of natural resources with reduced impact compared to previous methods. Other factors may contribute to communication problems: (1) there is not enough public knowledge of the comparison between past and recent environmental performance and achievements made by the industry, (2) the public is not familiar with current environmental performance monitoring, (3) there is a lack of public knowledge of environmental regulations and practices, and (4) technologies and processes in place and new technologies under development are not well known. Ecosystem dynamics and effects on human health are very complex, and so local correlation may not have any causal relationship; but it is very difficult to refute a claim of a causal relationship between a health issue and industrial development. Persistence of an environmental impact is not well understood. A short-term impact that naturally recovers to a self-sustaining ecosystem may be acceptable in the long term. Determining whether reclamation (artificial or natural) results in a return to equivalent environmental capability requires clear definition and long-term monitoring to agreed measurement criteria. 
The lack of common definitions and understanding of impacts aggravates the communication issue. This is an argument for establishing straightforward and effective measures of sustainability for the oil sands and heavy oil projects. These measures can be found through structured analysis of large hydrocarbon projects using common definitions. Oil sands and heavy oil projects have yet to take advantage of any of the systematic benefits that a sustainable rating system can provide; but there has been progress. Industry associations are attempting to develop common definitions and standards by which environmental performance can be assessed, and to move beyond ad hoc approaches. A rating system can facilitate this process by supporting owners, contractors, government, and the public in general throughout a project life cycle.

\section{Sustainable Rating System Development Methodology}

The development of the WA-PA-SU project sustainability rating system is an eight-stage process:

(1) Understanding oil sands and heavy oil projects' structure and their environmental regulations and standards.

(2) Considering the role of project management in the integration of design, planning, execution, and operations into green and sustainability practices.

(3) Using environmental and sustainable assessment tools as part of the development of the sustainable rating system.

(4) Creating the sustainable rating system structure (subdivisions, areas of excellence, and criteria).

(5) Using rating systems as environmental impact assessment performance tools.

(6) Developing the rating system scale and credit weighting tool based on five criteria: energy consumption, greenhouse gas emissions, water and terrestrial impact, relevance in the project, and investment (Quantitative Assessment).

(7) Obtaining industry and expert feedback to generate consensus.

(8) Verifying the sustainable rating system through a case study.

A sustainable rating system goes beyond standards and regulations. The main objective is to accomplish excellence in environmental performance, not to meet government and environmental agency requirements; however, these have been included in the design of the weighted rating scale, since a company must meet legal requirements as a minimum condition for maintaining its operating licence. While oil sands and heavy oil projects may be developed around the world the sustainable rating system development focuses on Canadian processes and practices, mandatory regulations imposed by government and non-government organizations, and non-compulsory internal and external standards, requirements, processes, and procedures.

Existing sustainable rating systems do not consider environmental management to be sufficiently relevant to have management processes as criteria, nor do they allocate many points for project management in the rating scale. In this respect, ratings are more outcome-based than process-based, which ignores the established concept that management - the planning phase in particular-is the basis for the success of a project. The rating system methodology looks at the significance of management in delivering excellence in environmental performance. Some areas included to support the relevance of management in green and sustainable projects are: [a] integration of sustainability and project management, [b] implication of integrated design in different phases of the project planning, execution, and operation, and [c] role of management in green and sustainable decision making processes. One example of management's role is justifying additional capital costs on more sustainable materials and practices for a project on the basis of long-term returns.

Environmental and sustainable assessments have been used around the world and across almost every industry (Fischer, 2007; Gibson et al., 2010; Therivel et al., 1992; Dalal-Clayton and Sadler, 2008). In addition, environmental risk management has also become relevant in the assessment of environmental performance (Pritchard, 2000). Conceptual challenges are encountered at this stage of development: uniqueness of the oil sands and heavy oil projects, complexity of processes and procedures, and geographical location of projects. The development of a sustainable ratings system must take these aspects into consideration to integrate the accurate environmental assessment tool into the weighting scale, to pre-assess the projects for a preliminary structure of the sustainable rating system, and to apply an appropriate existing environmental assessment process (or consider developing one) to address the specific assessment requirements of oil sands and heavy oil projects. Three areas are part of the environmental and sustainable assessment: energy consumption, greenhouse gas emissions (e.g., carbon dioxide, water vapour, methane, and ozone), water and terrestrial impacts, and/or 
relevance factor. These three factors are considered when developing or adjusting existing sustainable and environmental assessment tools to the needs of the sustainable rating system.

Sustainable rating systems use various forms of categories and classification to differentiate the requirements for a specific area, or resources and criteria that fall under them. This structure consists of: [a] Project phase, in which identified criteria are classified according to which project phase it follows under (e.g. planning, construction, operation); [b] Subdivisions of the project. , which divides the project into different areas to easily manage the complex and distributed project information, classify the criteria, and facilitate the applicability of the sustainable rating system; [c] Areas of excellence, which are groupings that make logical sense for the system, and which align with frameworks for managing the project and its ongoing operations, with each subdivision of the project containing the areas in which criteria follows under; and [d] Criteria, which are identified according to three factors related to sustainability: energy consumption, greenhouse gas emissions (e.g., carbon dioxide, water vapour, methane, and ozone), and/or sustainability relevance factor, and then classified and allocated under each subdivision, area of excellence, and project phase.

Implementation of a sustainable rating system usually encounters challenges. To highlight benefits and potential contribution to the industry, government, society, and environment, a series of ongoing activities are planned to gauge the alignment of a rating system with current practices related to assessing environmental and social impact, to introduce the sustainable rating system to practitioners, to engage government agencies (such as Alberta Environment) and non-government organizations, and to conduct informal interviews with members of industry associations and other groups.

The first part in this stage is to develop a rating scale. According to the number of points allocated to a project by meeting the different criteria, which includes environmental standards and regulations, the green and sustainable level will be designated. A comparative study is considered, taking into consideration other sustainable ratings systems presently used around the world. Decision making theories and mathematical models are applied when designing the rating system scale. Going from one level to another in the rating scale requires developing a theoretical model. Ease of implementation and alignment with business processes will be considered, but these implementation issues do not drive the selection of criteria.

The second part in this stage consists of the development of a credit weighting tool. Different sustainable rating systems use weighting scales as a tool to allocate points to each criteria. The allocation of the points to each criteria is critical. The proposed principle of the credit weighting tool is based on considering four main criteria to allocate points: relevance of the criterion to the project, greenhouse gas emissions, water and terrestrial impacts, and energy consumption.

One of the most difficult challenges faced by the sustainable rating system development will be encountered during its validation process, for several reasons. Due to the magnitude of the oil sands and heavy oil projects, it is nearly impossible to persuade the industry to implement the sustainable rating system without substantial evidence of its utility. Due to the time frame required to determine whether project decisions have positive or negative long-term impact, short case studies would not collect enough information to prove the rating system benefits. A qualitative approach to verification of the method can be taken through surveys or interviews to obtain feedback on different aspects of the ratings system, such as: [a] structure, [b] practicality and viability, [c] the credit weighting points tool, [d] the rating scale, [e] sub-divisions, areas of excellence, and criteria, and [f] the future of the rating system and willingness to implement it.

The consistency of the sustainable rating system can be evaluated and tested by using available public data for existing projects, even though they are not following a decision-making process based on the system. Since there are no parameters for comparison with other rating systems (because of the lack of sustainable rating systems for oil sands and heavy oil projects), expert opinions and environmental studies results of existing projects is compared with the results obtained using the WA-PA-SU project sustainability rating system. This comparative approach should highlight areas for improvement. Based on the results obtained during a verification process, the sustainable rating system structure will be modified if necessary, and criteria weighting will be adjusted. According to the results obtained in this stage, the rating scale proposed in stage six is assessed and/or verified.

\section{Discussion}

The WA-PA-SU project sustainability rating system has been conceived to contribute to more sustainable development of oil sands and heavy oil projects, by assisting with the implementation of enhanced strategies to enhance positive environmental, health, economic, and social impacts from project developments.

Following the model of other sustainable ratings systems developed for buildings, such as LEED, the sustainable rating system is designed to allow adjustment for changes in regulations, market demands, and requirements, 
processes, and procedures (within and external to the owner/operator company). Another relevant characteristic of the sustainable rating system consists of the potential to be adapted to other industry sectors or jurisdictions.

The development of the WA-PA-SU project sustainability rating system is based on the applicability of the benefits already identified in the implementation of existing sustainable ratings system for buildings. These benefits are expected in the areas of economic contribution, productivity, risk management, health, public relations, employee recruitment and retention, and other areas (Yudelson, 2008).

Considering the challenges that oil sands and heavy oil projects are facing, their potential to deliver positive benefits while mitigating negative effects, and the contributions and benefits that a sustainable rating system possesses, there would likely be great benefit to having a project sustainability rating system that project stakeholders can endorse and use.

The development of the sustainable rating system consists of eight different stages, which have been identified and take into account the relevance, environmental requirements, limitations of owners and constructors, limited availability of information, and expectations of the stakeholders of the projects in question.

Future work will focus on developing appropriate criteria with measures that will be accurate, simple to measure, and having weighting scales that are appropriate and relate as much as possible to established decision-making (such as having decision aligned with business units). Specific topics for future work are:

(1) Establishing a structure consisting of a) the project life cycle phases that the sustainable rating system will support (e.g. planning, construction/execution, operation, etc). b) different subdivisions due to size and complexity into which the project will be divided, and c) areas of excellence in which the different criteria fall;

2) Developing the credit weighting tool, the rationale and mathematical model behind the allocation of credits points will be discussed;

3) Setting the rating scale and criteria, which will be classified according to project life cycle phases, area of excellence, and subdivision, and

4) Conducting a case study to verify the process for using the rating system, and to understand how measurements should be made for validation of the weightings.

The results of this future work will be published as they develop.

The WA-PA-SU project sustainability rating system is intended to act as a bridge amongst all parties to work with a common goal in mind: to make large industrial projects, such as oil sands and heavy oil developments, more sustainable for the benefit of Canadian society, its economy, and the environment.

\section{References}

Alberta Energy. (2009). Oil Sands 101. Retrieve from http://www.energy.alberta.ca/OilSands/1723.asp

Alberta Energy. (2011a). Oil Sands Acts and Regulations. Retrieve from http://www.energy.alberta.ca/OilSands/810.asp

Alberta Energy. (2011b). Facts and Statistics. Retrieve from http://www.energy.alberta.ca/OilSands/791.asp

Canadian Association of Petroleum Producers. (2009). Responsible Canadian Energy ${ }^{\text {TM }}$ Oil Sands Progress Report. Retrieved from Canadian Association of Petroleum Producers Web site: http://www.capp.ca/rce/reports/oilsands/Pages/default.aspx\#kI7oAi4K5vv9

Canadian Association of Petroleum Producers. (2010). Overview: Water Use in Canada's Oil Sands. Retrieve from Canadian Association of Petroleum Producers Web site: http://www.capp.ca/getdoc.aspx?DocId=154986\&DT=NTV

Cetron, M. J., \& Davies, O. (2010). Trends shaping tomorrow's world forces in the natural and institutional environments. Futurist, 44(4), 38-53.

Dalal-Clayton, B., \& Sadler, B. (2005). Strategic environmental assessment: a sourcebook and reference guide to international experience. .London: Earthscan Publications Ltd.

Eid, M. (2004). Rethinking relationships in the construction industry: integrating sustainable development into project management processes (Doctoral dissertation). University of Edinburgh, Edinburgh, UK.

Fischer, T. B. (2007). Theory \& practice of strategic environmental assessment. London: Earthscan Publications Ltd.

Fenner, R.A., \& Ryce, T. (2008). A comparative analysis of two rating system, Part 1 (Evaluation). Proceedings of the Institution of Civil Engineers, Engineering Sustainability Journal, 161, (Issue ES1), 55-63. 
Fenner, R.A., \& Ryce, T. (2008). A comparative analysis of two rating system, Part 2 (Evaluation). Proceedings of the Institution of Civil Engineers, Engineering Sustainability Journal, 161, (Issue ES1), 65-70.

Galvao, E.R.V.P., Rodrigues, M.A.F., Barillas, J.L.M., Dutra Jr., T.V., SPE, \& Da Mata, W. (2009). Optimization of operational parameters on steamflooding with solvent in heavy oil reservoirs. SPE Latin American and Caribbean Petroleum Engineering Conference Proceedings, Cartagena, Colombia, 2, 829-836.

Gibson, R. B., Hassan, S., Holtz, S., Tansey, J., \& Whitelaw, G. (2005). Sustainability assessment: criteria and processes. London: Earthscan Publications Ltd.

Haapio, A., \& Viitaniemi, P. (2008). A critical review of building environmental assessment tools. Environmental Impact Assessment Review, 28, 469-482.

Hellmund, A., Van Den Wymelenberg, K., \& Baker, K. (2008). Facing the challenge of integrated design and project delivery. Energy Engineering, 105(6), 36-47.

Hellmund, A. J., Wymelenberg, K. G., \& Baker, K. (2008). Facing the challenges of integrated design and project delivery. Strategic Planning for Energy and the Environment, 28(1), 69-80.

Herbst, A. M. (2004). Alberta Oil Sans: supply security just a pipeline away. Pipeline \& Gas Journal. 231 (11) 12-14.

International Energy Agency. (2010). World Energy Outlook 2010. OECD - Organization for Economic Co-operation and Development. Paris, France.

Issa, M.H., Rankin, J.H., \& Christian, A.J. (2009). A methodology to assess the costs and financial benefits of green buildings from an industry perspective. Canadian Society for Civil Engineering, Proceedings, Annual Conference, Canadian Society for Civil Engineering, Montreal, QC, 2, 1111-1120.

Kats, G. (2003). The costs and financial benefits of green buildings. Retrieve from http://www.usgbccolorado.org/downloads/articles/Kats-Green-Buildings-Cost.pdf

Kelly, G. (2009). The Oil Sands - Canada's Path to Clean Energy?. Cochrane, AB.: Kingsley Publishing Service Inc.

Luhning, R.W., Das, S.K., Fisher, L.J., Barker, J., Grabowski, J., Engleman, J.R., Wong, S., Sullivan, L.A., \& Boyle, H.A. (2003). Full scale VAPEX process - climate change advantage and economic consequences. Journal of Canadian Petroleum Technology, 42(2), 29-33.

Matthiessen, L. F., \& Morris, P. (2004). Costing green: a comprehensive cost database and budgeting methodology. Retrieve from http://www.davislangdon.com

Moritis, G. (2007). Alberta bitumen development continues its rapid expansion. Oil \& gas Journal, 105(26), 43-50.

New Buildings Institute. (2003). Integrated energy systems - productivity and building science. Sacramento, CA: California Energy Commission.

Nicklas, M. H., \& Bailey, G.B. (1996). Analyses of the performance of students in daylit schools. Raleigh: Innovative Design.

Nikiforuk, A. (1997). Alberta's new oil boom. Canadian Business, 70 (10), 52-57.

Oil Sands Developers Group. (2009a). Regulations. Retrieve from http://www.oilsandsdevelopers.ca/index.php/thank-you/oil-sands-facts/regulations/

Oil Sands Developers Group. (2009b). Rules and Regulators. Retrieve from http://www.oilsandsdevelopers.ca/index.php/thank-you/oil-sands-facts/environment/rules-regulators/

Oil Sands Discovery Centre. (2010). The oil sands story: in-situ. Retrieve from http://www.oilsandsdiscovery.com/oil_sands_story/insitu.html

Post, N. M. (2007). Gurus seek a building rating system with even greener pastures. Engineering News-Records, 258(8), 22.

Pritchard, P. (2006). Environmental risk management. London: Earthscan Publications Ltd.

Rajendran, S., Gambatese, J., A., \& Behm, M., G. (2009). Impact of green building design and construction on worker safety and health. Journal of Construction Engineering and Management, 135(10), 1058-1066.

Roodman, D. M. \& Lenssen, N. (1995). Worldwatch Paper \# 124: A building revolution: how ecology and health concerns are transforming construction. Washington, DC: Worldwatch Institute. 
Smith, T. M., Fischlein, M., Suh, S., \& Huelman, P. (2006). Green building rating systems: a comparison of the LEED and green globes systems in the US. Retrieve from http://www.dnr.state.md.us/ed/Green_Building_Rating_UofM.pdf

Sunshine Oilsands Ltd. (2011). Oil Sands technology. Retrieve from http://www.sunshineoilsands.com/operations/technology.html

Therivel, R., Wilson, E., Thompson, S., Heaney, D., \& Pritchard, D. (1999). Strategic environmental assessment. London: Earthscan Publications Ltd.

United Nations. (1987). Report of the World Commission on Environment and Development. General Assembly Resolution 42/187, 11 December 1987. Retrieve from http://www.un-documents.net/k-001303.htm

U.S. Environmental Protection Agency. (2010). Green building basic information. Retrieve from http://www.epa.gov/greenbuilding/pubs/about.htm

U.S. EPA. (2010). Guide to purchasing green power. Retrieve from http://www.epa.gov/greenpower/documents/purchasing_guide_for_web.pdf

U.S. Government Accountability Office. (2007). Crude oil: uncertainty about future oil supply makes it important to develop a strategy for addressing a peak and decline in oil production (GAO-07-283). Washington, DC.

U. S. Green Building Council. (2009a). LEED - Leadership in energy and environmental design: green building rating systems, Version 1.0 US Green Building Council.

U. S. Green Building Council. (2009b). USGBC LEED Green Associate Study Guide. Washington, DC: U.S. Green Building Council.

U. S. Green Building Council. (2011). Intro - What LEED is. Retrieve from http://www.usgbc.org/DisplayPage.aspx?CMSPageID=1988

Vreenegoor, R., Hensen, J., \& De Vries, B. (2008). Review of existing energy performance calculation methods for district use. Proceedings of the Symposium Gebouwsimulatie: Ontmoeten \& Ontdekken, Eindhoven, Nederland, 1-8.

Watkins, E. (2007). Investing in oil sands. Oil \& gas Journal, 105 (28), 30.

Wu, P., \& Low, S. P. (2010). Project management and green buildings: lessons from the rating systems. Journal of Professional Issues in Engineering Education and Practice, 136(2), 64-70.

Xiaoping, M., Huimin, L., \& Qiming, L. (2009). A comparison study of mainstream sustainable/green building rating tools in the world. International Conference on Management and Service Science, MASS 2009, Proceedings - International Conference on Management and Service Science, MASS 2009, Wuhan, CN, 1-5.

Yates, A. (2001). Quantifying the business benefits of sustainable buildings: summary of existing research findings, Project Report \# 20399., Watford, UK: Building Research Establishment, Center for Sustainable Construction.

Yudelson, J. (2008). The Green Building Revolution. Washington, D.C: Island Press.

Note 1. "The first white man to see bitumen from the largest oil deposit in Canada was Henry Kelsey, manager of the Hudson's Bay Company (HBC) at York Factory in 1719, when a Cree, Wa-Pa-Su, brought him a sample." (Kelly, 2009). 
Table 1. Building rating systems and developers

\begin{tabular}{|c|c|}
\hline Name & Developer \\
\hline ATHENA & ATHENA Sustainable Material Institute. Canada \\
\hline BEAT 2002 & Danish Building Research Institute (SBI). Denmark \\
\hline BeCost & VTT. Finland \\
\hline BEES 4.0 & $\begin{array}{l}\text { U.S. National Institute of Standards and Technology } \\
\text { (NIST). USA }\end{array}$ \\
\hline BREEAM & Building Research Establishment (BRE). UK \\
\hline CASBEE & $\begin{array}{l}\text { Industry-academic-government collaboration, support of } \\
\text { the Ministry of Land, Infrastructure, Transport and } \\
\text { Tourism. Japan }\end{array}$ \\
\hline DGNB & German Sustainable Building Council. Germany \\
\hline Eco Effect & Royal Institute of Technology (KTH). Sweden \\
\hline EcoProfile & Norwegian Building research Institute (NBI). Norway \\
\hline Eco-Quantum & IVAM. the Netherlands \\
\hline Envest 2 & Building Research Establishment (BRE). UK \\
\hline $\begin{array}{l}\text { Environmental Status Model } \\
\text { (Miljostatus) } \\
\end{array}$ & $\begin{array}{l}\text { Association of the Environmental Status of Buildings. } \\
\text { Sweden }\end{array}$ \\
\hline EQUER & $\begin{array}{l}\text { Ecole des Mines de Paris, Centre d'Energetique et } \\
\text { Procedes. France }\end{array}$ \\
\hline ESCALE & CTSB and the University of Savoie. France \\
\hline GBTool 2005 & $\begin{array}{l}\text { iiSBE, International Initiative for a Sustainable Built } \\
\text { Environment. }\end{array}$ \\
\hline Green Globes & $\begin{array}{l}\text { Green Building Initiative for green building design, } \\
\text { operation and management. USA }\end{array}$ \\
\hline Green Start & GBCA, Green Building Council of Australia. Australia \\
\hline Green Start NZ & $\begin{array}{l}\text { NZGBC, New Zealand Green Building Council. New } \\
\text { Zealand }\end{array}$ \\
\hline GRIHA & The Energy and Resources Institute. India \\
\hline HKBEAM & Beam Society. Hong Kong \\
\hline LEED & U.S. Green Building Council. USA \\
\hline LEGEP & University of Karlsruhe. Germany \\
\hline NABERS & $\begin{array}{l}\text { Australian Dept. of Environment and Heritage (DEH). } \\
\text { Australia }\end{array}$ \\
\hline PAPOOSE & TRIBU. France \\
\hline
\end{tabular}




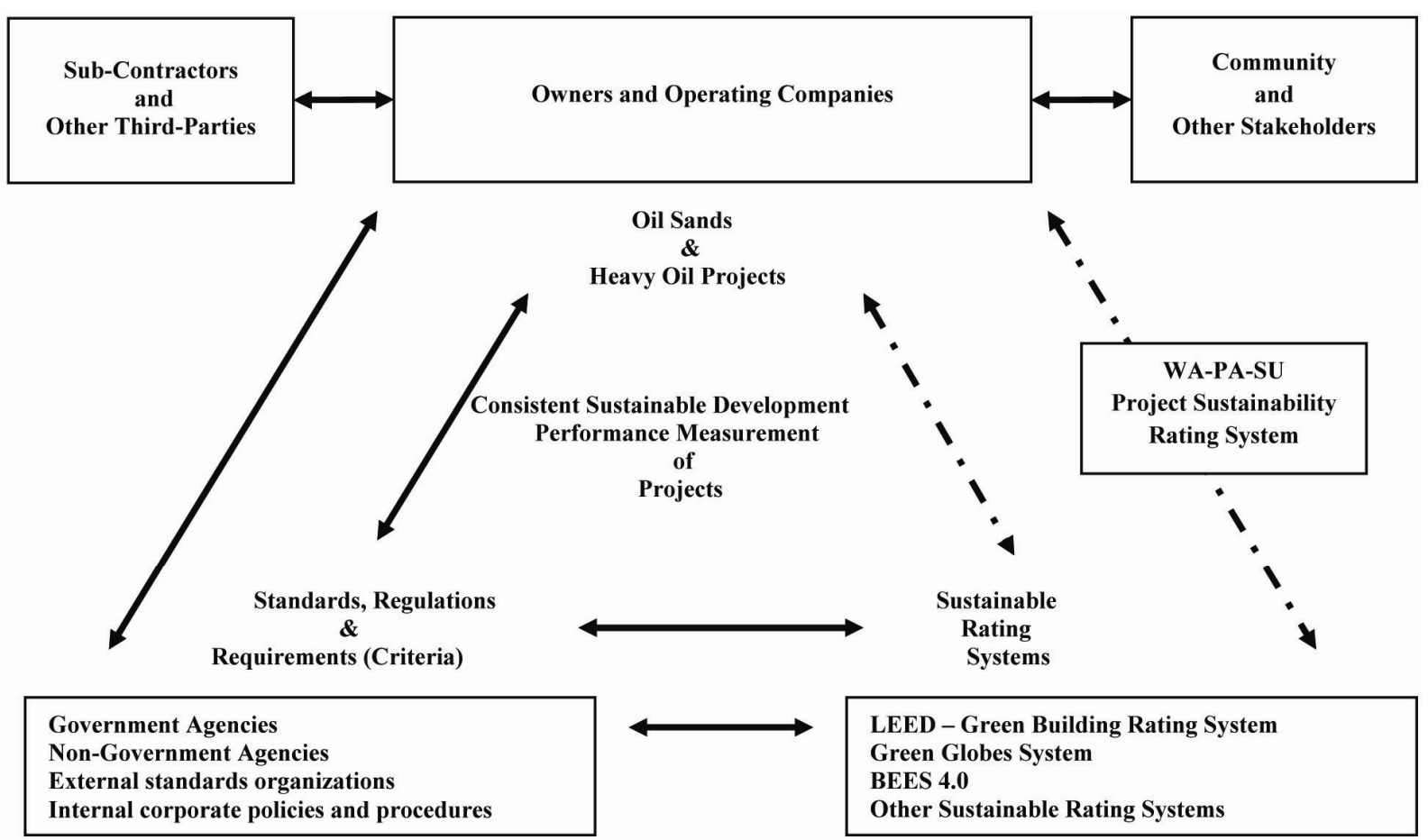

Figure 1. Relationships amongst Areas of Integration and Sustainable Rating Systems

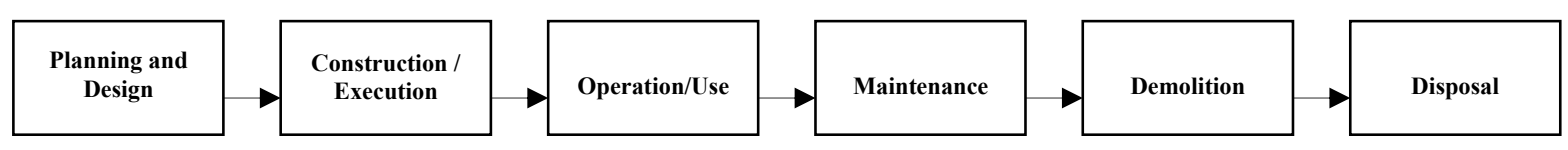

Figure 2. Phases of life cycle of a building 